\title{
Bathroom as a modern space
}

\section{Meltem Ö. Gürel}

Mundane objects and their everyday practices contain clues to the prevalent ideas and ideals of a society at a certain time; thus holding the power to decipher collective ideologies, contemporary beliefs, social norms and shared values. Bathroom fixtures are such ordinary products of the built environment that seem to be simultaneously insignificant and indispensable parts of daily life. This study is an historical analysis of the bathroom as a social space and of its fixtures as material culture. It reflects ideas and identities around the convoluted notions of modernisation and Westernisation in the Turkish context. It suggests that the values of being modern contributed to the transformation of traditional bathroom practices through spatial mechanisms and equipment. To unpack these values, the study engages the examination of oral histories, literary works, journals and flat plans as well as extant bathrooms. The research shows that the bathroom is a product of global modernity. Mediated through flats, which proliferated as a sign of contemporary living, the Western-style bathroom became the norm while its traditional counterpart became its other. This shift in perception indicates a concern for belonging to the world civilisation in the form of an aspiration toward being Western. A universal idea of modernisation pervades the ordinary domestic space of the bathroom and its everyday practices.

\section{Introduction}

During the course of the twentieth century, the bathroom habits of urban dwellers in Turkey by and large changed, and domestic designs with ideas of modern living appear to have had a leading role in manifesting this change. The way a person used the lavatory and washed the body were transformed through a notion of modernity; the new bathroom space was designed to accommodate, as well as to bio-power this notion. ${ }^{1}$ I argue that discourses on modernity were the means by which people were implicated and influenced. ${ }^{2}$ That is, values and beliefs formed in response to discursive forces acting on being modern contributed to the transformation of traditional bodily practices through spatial mechanisms and equipment. In the course of its modernisation, the bathroom served as an instrument in importing Western ideas of comfort and hygiene. How were bodily practices transformed to what is now considered 'normal'? How did lavatory fixtures contribute to forming a modern consciousness? How and when did notions around modernity operate in domestic space through bathroom designs? What do the spatial effects of these designs suggest on a broader scale?

Modernity can be considered to be a subjective experience - ie, how people experience everyday life - that requires an explanation for the current condition. Accompanied by social changes, it unfolds in many ways. As Marshall Berman tells us, 


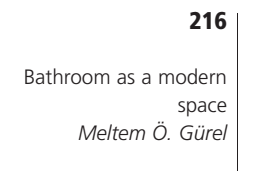

modernity is a double-edged sword: the modern condition is the contradiction between disintegration and renewal. ${ }^{3}$ In modern history, the materiality of the bathroom space epitomises this ambiguity: it embodies the destruction of the old, traditional, familiar and inherent as well as the introduction of the new, progressive, up-to-date and extraneous. Accordingly, it simultaneously evokes a notion of living in a modern juncture and of an alienation from the customary practices and values of a society on the verge of socio-political transformations shaped by global aspirations. In this respect, the Turkish case constitutes a useful example that can be compared to transformations elsewhere.

To scrutinise the bathroom as a site of social change shaped by discursive forces, this study engages multiple methods, including analyses of texts, built form, material culture and oral histories. The texts examined are publications by architects and critics as well as literary works that address spatial and cultural issues around bathrooms. The plans and extant structures focused on are of flats, which were celebrated as 'modern' by architects and users when they were first built. I conducted interviews in an informal life-history format with three wellknown architects over the age of 80 , who built such structures during the 1950s to the 1970s, and with 21 users who resided in these or similar multistorey blocks of flats (or apartment buildings). The users were middle- and upper-middle class women, now in their late sixties to their eighties (14), older daughters (4), husbands (2), and one brother. Oral histories are used to chart personal experiences and to unpack the spatialisation of socio-cultural norms and concepts around modernity.
Housing Western fixtures and new technologies, the modern bathroom proliferated in the first half of the twentieth century in Turkey. Early in the century, these could be seen in domestic handbooks, such as the Rehber-i Umur-u Beytiyye ('A Guide to Domestic Matters', 1903-1911), which was an outstanding example of the handbooks that portrayed Western ways of living to the late Ottoman elite. ${ }^{4}$ Western-style water closets, baths and hand basins were seen in residences that had been built by Europeans. They were also present in the late-1920s and 1930s domestic designs of Turkish architects who aimed to modernise the new nation, which emerged after Ottoman rule. Their work was widely informed by developments in Europe and in the United States, as well as by interwar architectural Modernism. ${ }^{5}$ Bathroom equipment and design became an important aspect of contemporary building culture for providing what came to be considered hygienic, comfortable and high living standards. Furthermore, they arguably signified social status and class as well as the conceptual formation of the inhabitants, including civic identity, cultural upbringing and educational background. These embedded meanings of the bathroom's materiality symbolised a sense of belonging to the industrial West.

A bathroom that combined a water closet (called an alafranga lavatory), a sink and a bath - thus involving the activities of bathing and using the lavatory - was an Occidental product that eventually became the hallmark of the contemporary domestic landscape, which included a mass of modern blocks of flats that proliferated in Turkey. ${ }^{6}$ Appropriation of this product can be connected to 
the idealisation of the modern bathroom that was developed toward the end of the nineteenth century in Europe and in the United States. Discourses on hygiene, mechanisation and comfort had a great impact on this idealisation. As Adrian Forty has pointed out, bathroom designs with white enamel fixtures and tiled walls illustrated in a British sanitary ware manufacturer's catalogues, starting in the early 1900s, reflected the value embedded in hygienic rationalism, which linked cleanliness and health to the solution of all social problems in Europe and the United States beginning in the 1890s. ${ }^{7}$ The rhetoric of prominent Modern architects also reflected these values. Le Corbusier conceptualised the bathroom as a large room, facing south, with a glazed wall, 'opening if possible on to a balcony for sun baths; the most up-to-date fittings with a shower-bath and gymnastic appliances' in Towards a New Architecture (1923). ${ }^{8}$ According to Adolf Loos, white - considered an evidence of cleanliness and health - was the only suitable colour for the bath. ${ }^{9}$ Extending moral impulsions, he conceptualised architecture as pure and clean. For Loos, improvements in urban sewage systems and water supply were great achievements of the nineteenth century, and the plumber was 'the billeting officer of culture. ${ }^{10}$ Loos considered Austrian bathroom equipment and plumbing inferior to English and US fittings. Universalising the conception of cleanliness, he acknowledged the US bathroom and bathing habits as thoroughly hygienic and modern. ${ }^{11}$

In Mechanization Takes Command (1948), Siegfried Giedion traced the development of the domestic American bathroom to the hotel building. The five-foot, double-shelled bath, developed in the United States around 1920, Giedion explained, standardised the bathroom unit and established the 'compact bathroom': what Americans called 'the rigid layout of the bath, basin, and toilet, and their compression within a minimum space'; the qualification for this was to align the fixtures along one wall (Fig. 1). ${ }^{12}$ Giedion considered the mass-produced, built-in white bath to be an object of standardisation as much as a symbol of modern bathing, for it not only provided cleanliness, but also attained 'a degree of comfort that had been pursued for thousands of years. ${ }^{13}$ Notably, Giedion recognised comfort as important and different from the hygienic order in studying the bathroom at a social level. ${ }^{14}$ However, his approach was undermined by a fallacy of ungrounded and prescribed ideas that were said to determine design. ${ }^{15}$

Significantly, Western concepts of the bathroom were not monolithic or unified. Furthermore, in reality, there were differences between an idealised bathroom and what many people used in daily life. Arguably, the modern bathroom became widespread after World War II, as US consumerism prevailed, especially in Western European countries. This pervasiveness played a leading role in the development, proliferation and internalisation of the Western-style combined bathroom in the Turkish domestic landscape.

\section{Bathroom fixtures: signs and symbols of Westernisation}

Traditionally, houses did not have a combined space for bathing and using the WC: the latter was often located outside the house in a courtyard or a garden and the user crouched over a basin with a 
Figure 1. 'American Compact Bathroom', 1908 and 1915, from the L. Wolff Co.,

Chicago, and Crane and Co., Chicago,

catalogues: S. Giedion, Mechanization Takes

Command (New York, W.W. Norton \&

Company, 1948/1975), p. 699.

Figure 2. A kurna in the Topkapı Palace, Istanbul (photograph by the author, 2007).
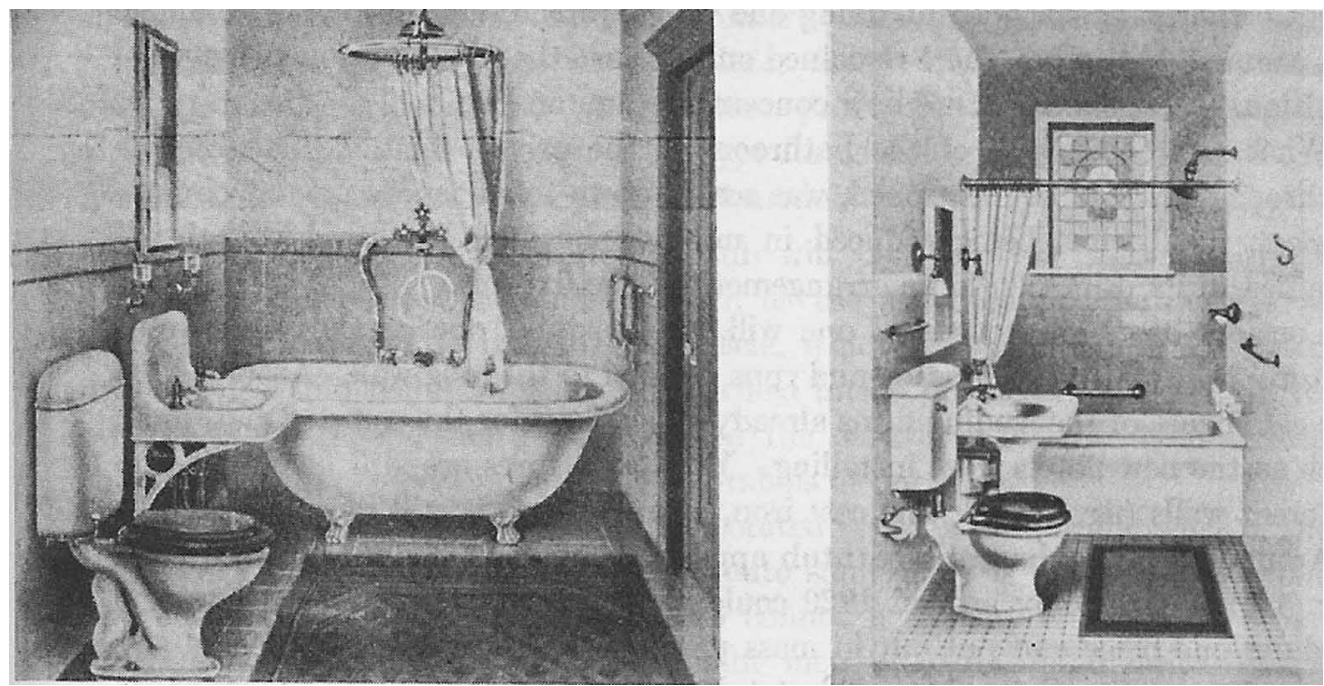

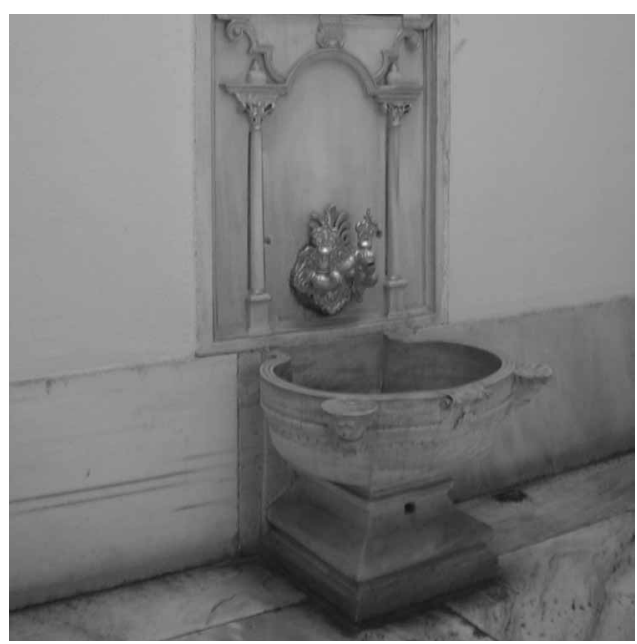

hole rather than sitting on a bowl. This fixture, still seen in Turkey and in many other locations worldwide (including Middle Eastern and Asian countries) in various forms, is called an alaturka (alla turca) lavatory in Turkish. ${ }^{16}$ Bathing was either carried out inside a room or, more extensively, in a Turkish bathhouse (hamam, Turkish; hammam, English). Bigger households had their private hammam, while each community or neighbourhood usually had a public one. The latter was also a space for socialising and for religious rituals. It was composed of four main areas: a spatial sequence of a dressing/ resting room (camegah or soyunmalık), a transitional/warm room (soğukluk or $ı$ lıklık) and a hot room (sıcaklık), along with a separate heating room (külhan). In both public and smaller private 
bathhouses, washing was done in a hot room equipped with water basins (kurna) from which water was poured with a cup or a bowl onto the body (Fig. 2). A closet-like bathing space (gusülhane) was located inside the rooms of a house to accommodate complete ablution. This small closet was supplied with water containers and drainage, and had a more private character than the hammam. It was a place where a married couple washed after sexual intercourse. ${ }^{17}$

Western bathroom concepts and fixtures became more recognisable and even applicable after the founding of the Turkish Republic, beginning with the leadership of Mustafa Kemal Atatürk in 1923. The new regime envisioned reconstructing the war-struck country as a modern European state by dissociating it from the Orientalist representations of the Ottoman Empire. With this mission, the new Republic launched a series of reforms that radically changed the social, political, cultural and economic structures of the country. Radical reforms carried out in the 1920s included the abolition of the caliphate and of Islamic law in 1924; the adoption of Western clothing (1925); the implementation of the Swiss Civil Code (1926); and the replacement of the Ottoman-Arabic script with the Latin alphabet (1928). These reforms can be related, in a philosophical premise, to the earlier Tanzimat (reorganisation) reforms $(1839,1876)$ under Ottoman rule. Both initiatives aimed to modernise the state by adopting Occidental models; however, the Kemalist reforms varied from the previous ones in their vigour and revolutionary nature. ${ }^{18}$ Aimed at shaping a new nation and its people, they operated both in the public and the private realms. The architectural and design culture of the 1930s, informed by the universalistic inclinations of interwar Modernism, served as means to this end.

During the 1930s, Western-style bathroom fixtures were incorporated into the domestic plans of Republican architects, who undertook the role of cultural leaders in introducing people to the modes of Western living. These plans appeared in architectural publications as well as in popular magazines, such as Yedigün, which reverberated with Republican ideals. Initially, model house plans published in Yedigün were taken from foreign publications. Therefore, they embodied ways of living that were unfamiliar to Turkish users. In the second half of the 1930s, the magazine introduced model home designs by Turkish architects in addition to foreign examples. While depicting modern lifestyles, these schemes also assimilated traditional elements into spatial compositions, which helped to overcome insensitivity to local customs. Most notably, an alaturka lavatory, separate from the bathroom, was incorporated into these plans to make them culturally responsive and popular to the public. ${ }^{19}$

During the second half of the twentieth century, alafranga lavatory fixtures and baths became the norm in home designs, which increasingly governed flats in the major cities of Istanbul, Ankara, and Izmir. The bath replaced the kurna, as the alafranga water closet displaced the alaturka basin, and with a supply of hot water, the two were combined into a modern bathroom (Fig. 3). While the combined bathroom indicated the present, the alaturka lavatory and the hammam came to be thought of as obsolete in a progressive domestic space. Conceptualised in a dichotomy, the two have arguably been 
Figure 3. Advertisements for electrical and gas water heaters for the modern bathroom (1950s Arkitekt journals).

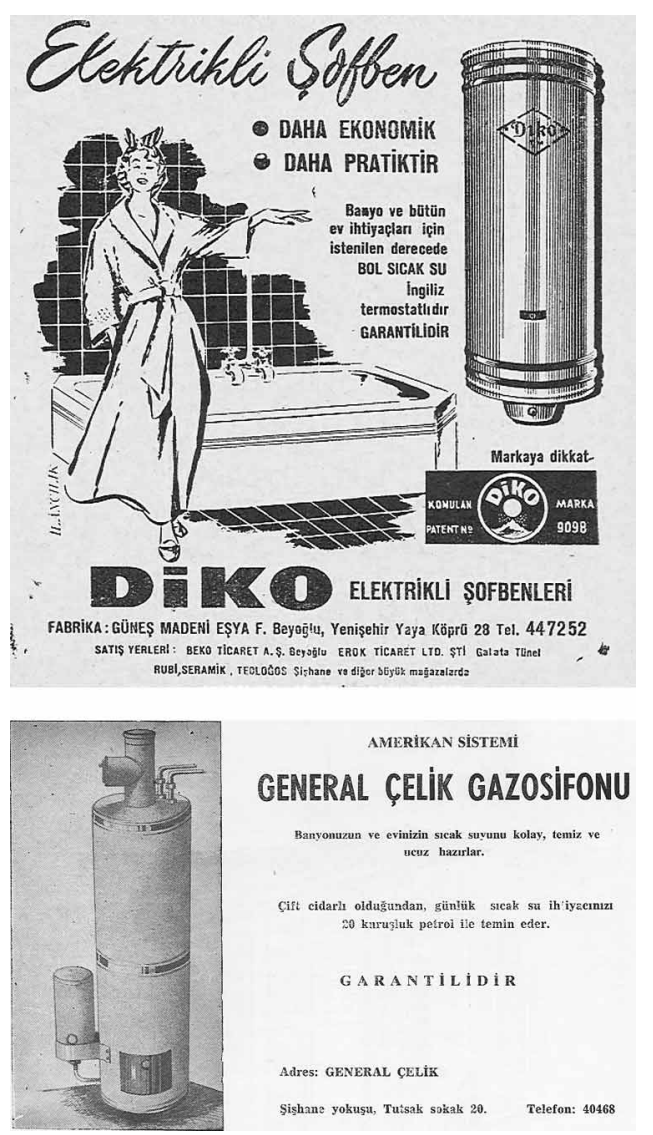

considered measurements of modernity on an axis of advancement and regression. Still, many architect-designed flat plans of the 1950s and 1960s for middle- and upper-income residents included a small wet space equipped with an alaturka lavatory in addition to an alafranga one, located inside the combined bathroom. However, this inclusion signified a shift in social norms and values with regard to bathroom practices. As will be discussed, the alafranga lavatory symbolised belonging to a universal world civilisation, and the alaturka was its opposite. Arguably, the proliferation of the block of flats and its conceptualisation as an expression of modernisation in major cities helped to promote the combined bathroom with its Western-style fixtures and with the socio-cultural values constructed around it.

\section{The bathroom and the flat}

The flat as modern domestic space was initially emphasised during the latter part of the nineteenth century in Turkey. Mostly located around Pera, Galata, Şişli, Nişantaşı and Taksim in Istanbul, latenineteenth and the early-twentieth century apartment buildings were widely associated with non-Muslim, urban dwellers. Accommodating multiple units under a single roof, their masonry (and later concrete) masses contrasted with the traditional wooden houses of the city. These buildings were comparable in scale and appearance to their Viennese and Parisian counterparts. ${ }^{20}$ Equipped with common laundry and service areas, courtyards and even tennis courts, they reflected a European mode of living that was extraneous to Ottoman families.

Non-Muslims of the upper-middle class who could not afford masonry mansions in Istanbul preferred flats, while the middle and lower classes lived in small terraced (or 'row') houses of two or three storeys. Until the end of World War I, the Muslim Turkish population of the city liked to live in singlefamily houses. ${ }^{21}$ The popularity of the Harikzedegan 
(Fire Victims) Flats (1919-1922) designed by Kemalettin Bey in Istanbul indicated a modification in lifestyles of the upper and middle classes; although these blocks of flats were intended for use by lowincome groups who had suffered from the 1918 fire, they became popular among the Turkish elite, who paid high rents to live there. ${ }^{22} \mathrm{~A}$ multi-storey apartment building (The Second Vakıf Hanı, 1928) designed by the same architect after the founding of the Republic became a prototype for highstandard housing in the capital city of Ankara. The units included modern bathroom fixtures. ${ }^{23}$

The popularity of flats during the first half of the twentieth century was partly due to modernised interiors, including bathrooms. The two were intertwined as symbols of being Western and living modern. The famous Turkish author, Yakup Kadri Karaosmanoğlu, conveyed this union in his novel, Kiralık Konak (Mansion for Rent, 1922), in which he wrote about the clash of lifestyles and values with regard to tradition and Westernisation between different generations in Istanbul towards the end of the Ottoman Empire:

... I cannot understand the meaning of living here in a nomadic state while there are such wonderful and new flats in Şişli. There is not even a functional bathroom in the whole house. To operate that bulky hammam requires preparation three days beforehand, burning three çeki [an old unit of weight or mass] of wood, frequently plastering the boiler, and regularly having the kurna repaired. Under these conditions it is not convenient to take a bath even once a month. Mr. Servet was becoming more attracted to the new style flats with electricity and bathrooms day by day ... He found the atmosphere he had been yearning for since his birth, in this neighbourhood of Istanbul and inside these new flats ... dazzled, he was wandering about from room to room, his fez in his hand. He was saying to himself, "This is "Salle a manger" this is "fumoir", here is the salon, this place is the library ...' and finally as he reached the doorknob of the alafranga washroom and bathroom, he went and looked at the street; the street created an image of a European city in his mind by means of its width, noise, telegram, telephone, tram wires, cars, rails passing, signs on its walls. ${ }^{24}$

This conception of the bathroom as an indication of modernisation and Westernisation also appears in the literary work of the following Republican period, such as in Karaosmanoğlu's Ankara (1934) and in Refik Halit Karay's Bugünün Saraylısı ('Today's Royalty', 1954). Both novels include descriptive examples of new bathrooms (as opposed to hammams) as signs of being modern and as a requirement for living comfortably. The latter portrays this association as well as presenting life in a flat as a desirable mode of living. The author writes about the conversion of a hammam into a bathroom to attain a comfort level associated with flats:

'I recommend', said [Atif], 'having a water tank built upstairs, terkoz cannot be relied on, it leaks, and it stops. We have it in our flat as well'.

... On the sixth day Ata Efendi went out very early after gazing at the bathroom - which still smelled of cement, lime, and plaster; yet with its shiny tiles, taps and white lacquered water 
Figure 4. A bathroom illustration from Twyford's manufacturing catalogue, 1930; the emphasis on comfort and beauty is as significant as hygiene (Twyford Bathrooms, Virtual Museum, http://www.twyford bathrooms.com).

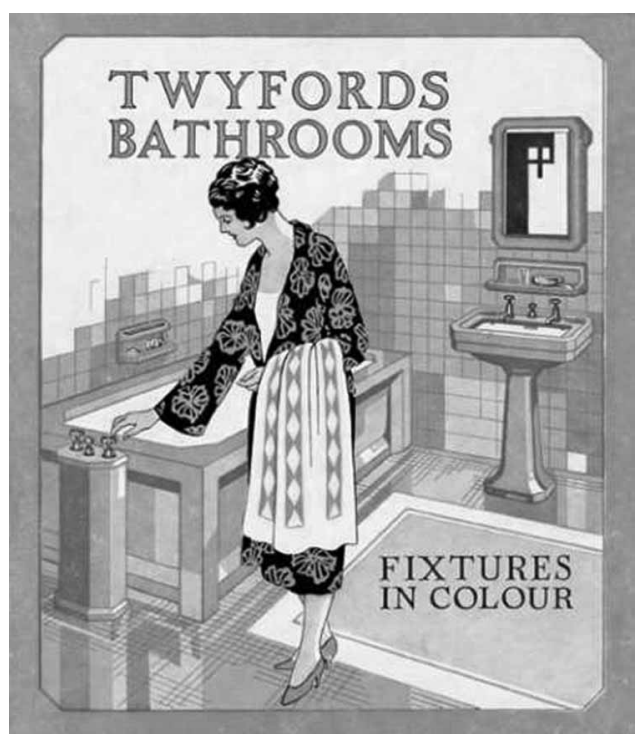

heater, it turned a corner of the house into a luxurious space. ${ }^{25}$

Early Republican architects also idealised flats with modernised bathrooms as a means of highstandard living. In 1939, Arkitekt - the country's first professional journal ${ }^{26}$ — published a wireless presentation by the architect Behçet Ünsal, who was a regular contributor to the journal. Entitled 'Cubic Building and Comfort', the manuscript pronounced the flat as a necessity of the 'machine age' and a realm of comfort. The bathroom was described as an important part of this realm. While still responsive to cultural priorities, the contemporary bathroom that Ünsal described introduced new ideas:
More than a bath room, this is a lounge. Beynovar is not just for bathing half of your body; you can lie down inside the water as you wish. But, perhaps you would not like to lie down inside the bath, like a sick person who is getting treatment. After all, washing with a kurna seems to be more hygienic for you. Eh, here it is; this bathroom has a kurna, as well. They did not forget about the shower above it, either. ${ }^{27}$

Ünsal's description of the bathroom as a comfort zone resonates with the emphasis placed on comfort and beauty. These considerations were as

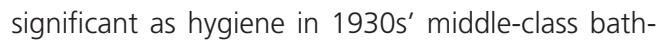
room designs: for example, those published in the manufacturing catalogues of Twyford, a British bathroom company (Fig. 4). ${ }^{28}$

This flat's bathroom also included traditional spatial components, such as a transitional space (soğukluk) between the bathroom and the bedroom. This was envisioned as a space where the bather could rest or have a massage. Different from its traditional counterparts, the contemporary bathroom was equipped with a continuous source of hot water and incorporated Western-style fixtures.

In this flat, there is hot water, but they also put a water heater [şofben] in that corner in case there is an operational problem with the hot water system; if something goes wrong, you can operate the heater by lighting it with a match. Here - mirror, double sink, bidet, alafranga WC - nothing is forgotten. ${ }^{29}$

Ünsal was among those Republican architects who acted as agents of modernisation and social rehabilitation. Their plans displayed changes in family 
structure and lifestyles, previously marked by the spatial segregation of gender. In an inaugural article in the first issue of Mimar, the architect, Aptullah Ziya, declared, 'Flat [apartman] life is the life of the twentieth century. The mansion and villa [konak and köşk] era in which brides, grooms, fathers and mothers all lived together is over. ${ }^{\prime 30}$ Contemporary schemes were appropriated for accommodating the nuclear family. Yet, by bringing together related nuclear families, many privately owned blocks of flats resembled a traditional Ottoman practice of living with the extended family. Family apartment buildings were common before the enactment of the Flat Property Law in 1965. Before this law, only buildings, and not the individual flats inside, could be owned.

During the 1930s and 1940s, multi-storey apartment buildings dotted the urban landscape along with single-family houses with gardens. Many of the 1930s buildings were examples of Modern architecture, characterised by cubic forms, rounded corners, unadorned surfaces, and the use of reinforced concrete. Their critics, who had nationalist sentiments, found them extraneous to local traditions and associated them with unhealthy living conditions. ${ }^{31}$ Flats were also connected to revenues and financial gains, because individuals or institutions that owned them rented them out for income. ${ }^{32}$ Despite such negative connotations, the flat was considered to be a sign of both a modern lifestyle and high social status.

In the following years, the multi-storey block of flats was transformed from a building type to a phenomenon that blanketed Turkish cities. This widespread phenomenon can be connected to two legis- lative measures that legitimised flat ownership: the 1954 Code and the 1965 Flat Ownership Law (Kat Mülkiyet Kanunu). According to the former, ownership depended on the percentage of shares held in a property. The latter defined each flat within a building as an individually owned entity. In fact, the massive production of multi-storey dwellings was a worldwide phenomenon that resulted from a complex web of political, economic, social, cultural and architectural circumstances affected by the Cold War. As was the case in many countries, ranging from Brazil to Greece, the notion of flatliving had taken a firm foothold in Turkey. Architectdesigned buildings of the 1950s and 1960s were largely rectilinear, prismatic masses of a standard height, distinguished by load-bearing systems of reinforced concrete, large windows, free plans and, importantly, combined bathrooms, which were furnished with alafranga water closets, baths, sinks and, often, bidets. Luxurious flats, finished with imported materials obtained through foreign exchange after World War II, were looked upon as symbols of status as much as property investments. ${ }^{33}$ Significantly, these flats were perceived as an economical housing model in an era of rapid urbanisation that was unfolding as a result of industrialisation. Composed of a number of regular residential units stacked on top of one another and served by a common vertical circulation core of lift/stair shafts, water and plumbing lines, the flat embodied standardisation, function, technology and affordability. ${ }^{34}$ Incorporating Western-style fixtures into bathrooms, the flat was celebrated as an expression of urbanisation, development, modernisation and hygienic living conditions. 
The water closet (WC)

The intertwined concepts of modernisation and hygiene have greatly affected the internalisation of the Western lavatory fixture. Although urban dwellers in metropolitan areas during the 1930s and 1940s knew of the alafranga water closet, many considered it to be a European mode of bodily practice and an undesirable way of using the lavatory. To some, it meant unacceptable hygienic practices. An upper-middle class user recalled her first encounter with a Western-style lavatory as follows:

I knew about the alafranga water closet, I just had not seen one before. When I walked into the bathroom at a home visit, first I did not know exactly how to use it. But, I was just too embarrassed to ask the hostess! Of course, I worked out that I was supposed to sit on it. But, the idea of sitting on something that other bodies had sat on irritated me. I did not want to touch this thing with my bare skin! So, I just crouched with my shoes on the top of it. ${ }^{35}$

Such feelings were common throughout the first half of the twentieth century. However, in time, this notion of hygiene switched. The traditional Turkish-style lavatory came to be perceived as dirty, outmoded and even uncivilised, while the Western-style lavatory was seen as hygienic and modern, especially by younger generations of certain cultural backgrounds in the major cities. As such, alafranga lavatory fixtures were incorporated into domestic designs. They became an integral part of life; the act of sitting on a water closet replaced crouching on an alaturka basin on the floor.
'Now, in my old age, I could not crouch over an alaturka lavatory because of my knees, even if they paid me' said the above interviewee, bringing another dimension to her earlier views. Yet, aside from physical reasons, this shift in preference from alaturka to alafranga lavatories shows the social nature of the notions of cleanliness and dirtiness. ${ }^{36}$ These are relative ideas socially constructed in response to discursive forces. The magnitude of this transformation in cultural priorities during a lifetime is, arguably, a product of regarding the alaturka fixture as obsolete and the alafranga water closet as progressive; conception of the Western-style lavatory as a symbol of being modern was central to its appropriation. In this respect, the water closet served as an apparatus that directed lives toward Westernisation. For the young citizen, who wanted to be considered modern, keeping traditional lavatory practices did not appear to be a choice.

Throughout the second half of the twentieth century, the Turkish-style lavatory came to be perceived as an old apparatus only appropriate for the 'traditional citizen'. As patrons and dwellers of a 1964 flat in Izmir aptly put it, a small alaturka lavatory, separate from the bathroom with a Westernstyle fixture, was included in flat plans for those who could not let go of their accustomed lavatory practices:

We included a separate small alaturka lavatory in our flat to accommodate the needs of our old father, who often visited our home, as well as of the domestic helper. However, we [the family] always used the alafranga water closet in the bathroom. We converted the alaturka lavatory into an alafranga after our father passed away. ${ }^{37}$ 

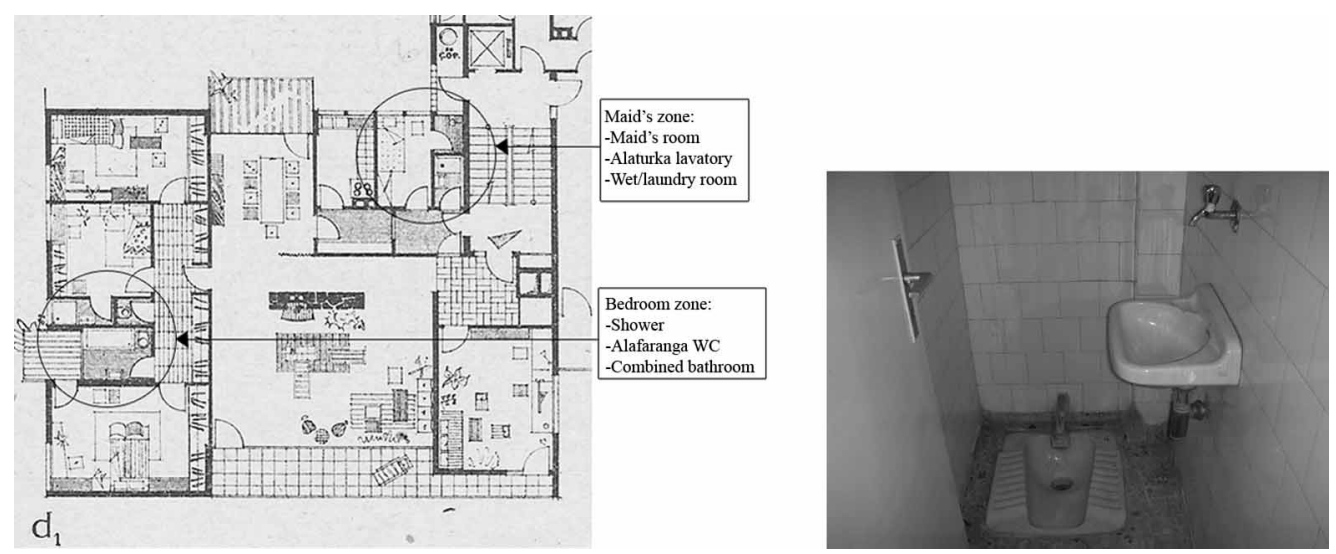

Figure 5. Block D unit plan, Ataköy Housing Development, Phase I (1957-1962), Istanbul, designed by E. Menteşe: Arkitekt, vol. 26, no. 291 (1958), p. 63. There is a spatial segregation between the family bathrooms and the alaturka lavatory adjacent to the maid's room in the service zone (photograph by the author, 2006).

While this common story illustrates the embodiment of progression, youth and modernisation through the contemporary bathroom space, it also suggests binary oppositions constructed around the lavatory. Furthermore, it exposes hierarchical class relationships operating in domestic space. $^{38}$

Many of the 1950s and early 1960s plans include a maid's room, which reverberated with the lifestyle of the Ottoman elite. ${ }^{39}$ One of the distinct characteristics of this room appears to be that it is adjacent to a small, wet space that contains a traditional Turkish-style lavatory. Designated for the use of the domestic assistant of lower strata, this wet space stands in stark contrast to the main bathroom, which is equipped with Westernstyle fixtures for the use of the 'modern' family. The inclusion of the alaturka lavatory as an extension of the maid's space in its difference from the family bathroom illustrates a spatialisation of the dichotomy between the concepts of modern and traditional, Western and non-Western, and hygienic and unhygienic.

This spatial segregation between the maid, identified by traditional bodily practices, and the contemporary family, identified with modern bathroom spaces, ironically appears in the four-bedroom units of the Ataköy Housing Development, Phase I (1957-1962) - one of the earlier Modernist blocks of flats built for middle- and upper-middle class residents in Istanbul (Fig. 5). This government-initiated housing project comprised 10 phases and continued until 1991. Ataköy was a colossal example of the modernisation and urbanisation efforts of the Democrat Party (DP) government, which came to power in 1950, concluding three decades of endemic one-party rule. It was envisioned as a modern satellite city for about 50,000 people (Fig. 6). ${ }^{40}$ Like the DP, the architectural expression and contemporary plans were 
Figure 6. Ataköy Housing Development, model of stages I \& II, M. Giray: Mimarlık, no. 15 (1965), p. 16.

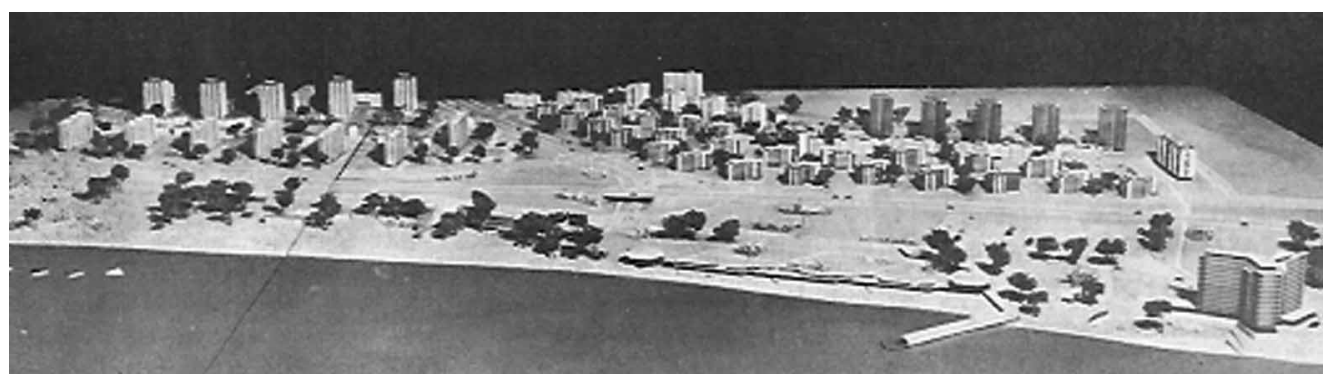

associated with democracy, liberalisation and modernisation.

'When we moved, we immediately converted the alaturka lavatory into an alafranga one, so that everybody could use it' explained a flat owner who moved to Ataköy in 1969. ${ }^{41}$ Many residents did the same, 'but many couldn't because it was needed', explained another resident. She had a number of renovations done to improve her flat, but the alaturka lavatory remained off limits for a number of years. 'Workers used it', she explained, but most importantly her domestic helper, a woman who migrated to Istanbul from the Eastern region of Kars, needed it. She worked for her for 25 years.

Once, I told her that I wanted to change the lavatory. She begged me not to do it. She said, 'Please Ms. Ayten this is how we have got used to using the lavatory.' So, I did not change it until she stopped working for me when she had cancer ... After that I changed it in the next renovations. $^{42}$

As it was for this woman, who was caught between tradition and change away from her hometown in the modern space of an Ataköy flat, a Turkish-style lavatory is still a part of bodily practices for a mass of people. However, it has not gone through modernisation. As such, it is a symbol of backwardness, underdevelopment and insanitary conditions in the eyes of people of a certain social status, cultural background and civic identity associated with the West. For those dwellers, the alaturka lavatory is a signification of the past, of anachronism, of rural tradition, of uncleanliness and, often, of lower strata. The same can be said for the Turkish hammam, which became outmoded and displaced as a centre of hygienic practices and leisurely activities. This unprivileged status of the alaturka lavatory and the hammam in the modern domestic space reflects the concepts of hygiene as social constructions that contribute to building and sustaining social structures.

\section{The bath}

During the 1950s, a built-in bath was a must for a bathroom to be considered 'modern'. It signified social status as much as Westernisation. Accordingly, the Ataköy flats, as icons of modernism, had 

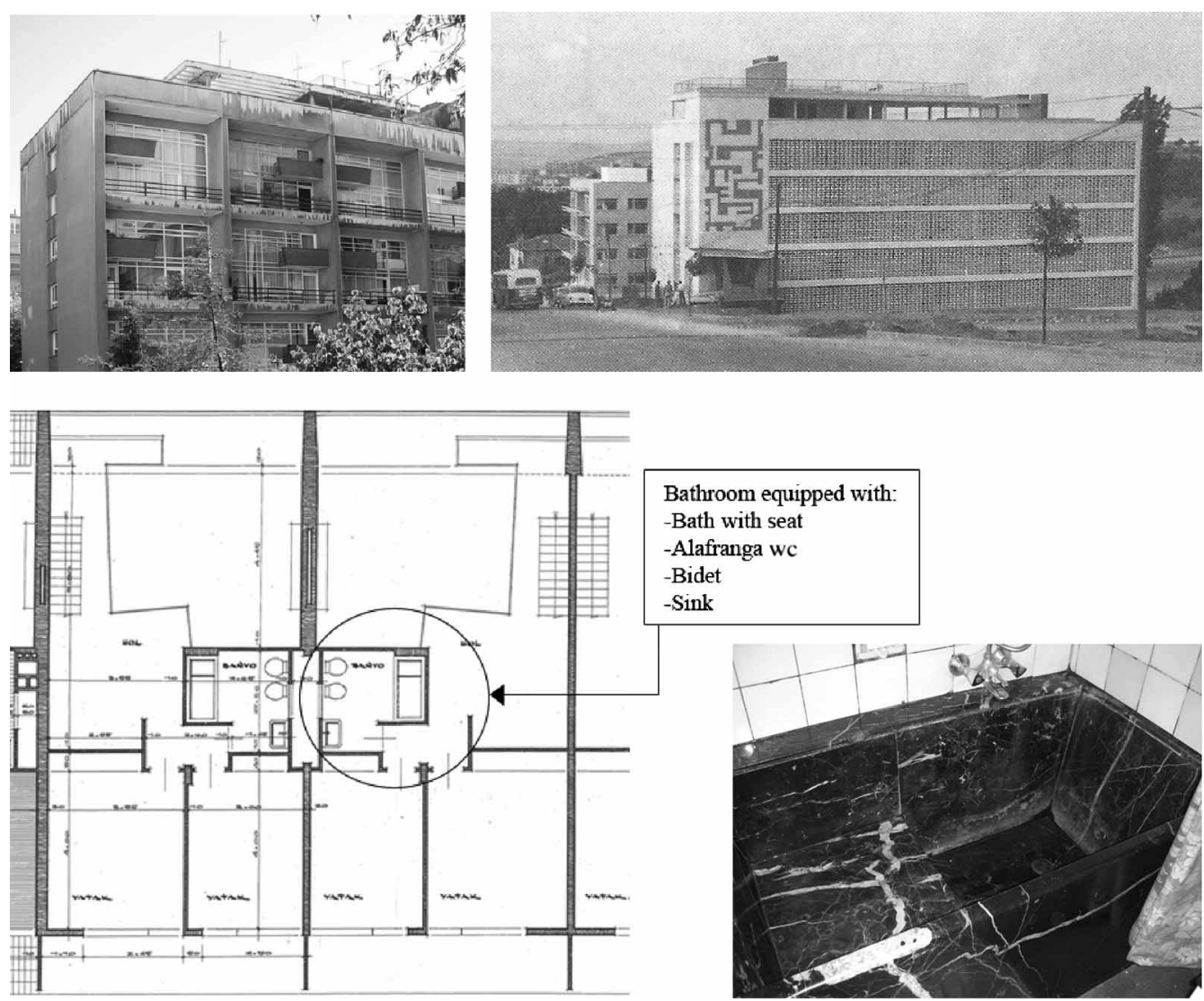

\section{Bathroom equipped with: -Bath with seat -Alafranga wc -Bidet -Sink}

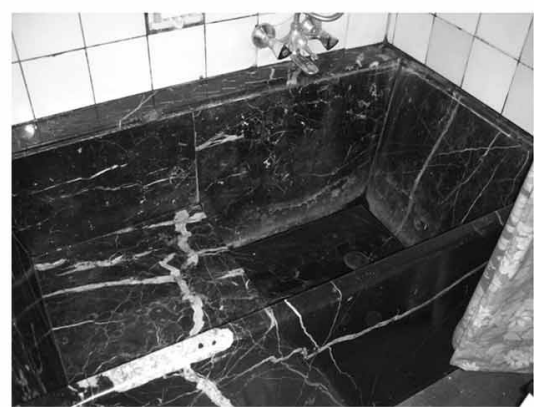

Figure 7. The DHMi Cooperative Apartment Building (1958-1960), Ankara, by N. Ersin: influenced by Le Corbusier's Unité d'Habitation, the block of flats has duplex units and a roof garden. Top: exterior photographs of the front and back façades taken, respectively, immediately after the completion of the building (right: courtesy of N. Ersin) and in 2006 (left: photograph by the author, 2006). Bottom left: upper-level plan of duplex units (courtesy of N. Ersin). Bottom right: bath with a seat designed by the architect (photograph by the author, 2006). baths in the family bathrooms, but the maid was only provided with a showerhead, squeezed into the small alaturka lavatory room with no shower basin. ${ }^{43}$ This was a poor solution, which was meant to accommodate the maid's ablutions. One could assume that the maid went to a neighbourhood hammam for bathing extensively, in other words, to attain a normative level of cleanness. Going to a hammam was still a common practice for many. On the other hand, a hammam was no longer considered a suitable place for 'modern' citizens; thus, the family was expected to enjoy the bath. However, the idea of washing the body in a bath filled with water was alien to bathing habits 
Figure 8. Bidet and alafranga lavatory in an un-renovated DHMi Cooperative flat (photograph by the author, 2006).

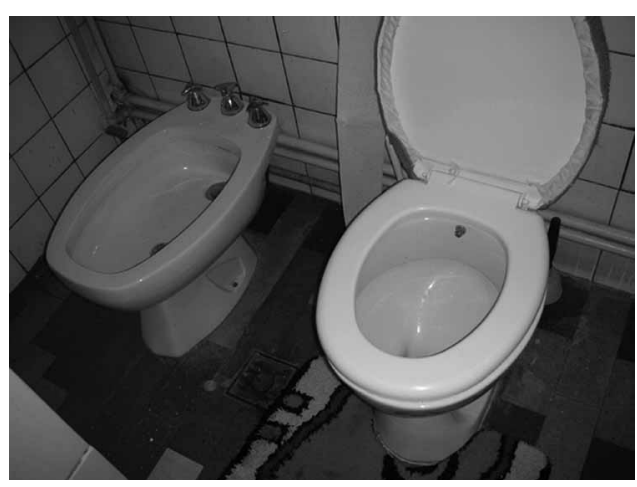

based on washing the body with running water. Still water was considered to be a favourable medium for breeding germs. Therefore, bathing in a bath full of water never wholly caught on in the hygienic norms of most dwellers. Although the bath took up roughly a quarter of the wet space, it was only used as a shower basin. ${ }^{44}$

As Nejat Ersin, a prominent Ankara-based architect, explained, the bath was in great demand during the 1950s; but it was not easy to find one. Suppliers quickly ran out of the limited number of baths, water closets and sinks, which were largely imported and expensive. This led to creative solutions. Ersin custom-designed the bath with a seat in black marble and had it built by a craftsman in the DHMi Cooperative Apartment Building (19581960), which was designed with influence from Le Corbusier's well-known apartment building, Unité d'Habitation (1947-1952) in Marseilles (Fig. 7). Ersin's design suited the traditional way of bathing by pouring water from a container while seated inside the bath. ${ }^{45}$ As the architect noted, many pre- ferred this arrangement because it was considered to be more flexible. The bath was also equipped with a showerhead, which complemented the hygienic norms.

Even though bathing in a bath was never popular, owning a bath became the standard. For many inhabitants, it was a redundant element in the personal space of the home, while for a marginal number of others it meant an occasional retreat. More often than for their intended purposes, the baths were utilised in other ways: as shower basins, for household cleaning tasks, for washing large items, and even for storing water when the water cuts implemented by municipalities became a way of life in urban areas, especially during the 1970 s. $^{46}$ The baths were filled with water to carry out domestic tasks. ${ }^{47}$ The bath appears to be a modest object compared to the leisurely Jacuzzis - published in popular and trade magazines, and included in luxurious villas after the 1980s. This is not to say that the former do not create a leisurely environment, as did the kurna in the context of a hammam, but to suggest that it is less a symbol of leisure than a commodity of domination as much as it is a tool of Westernisation.

\section{The bidet}

More alien than the bath was the bidet, which was used in France and continental Europe, but never really became popular in Britain and the United States. Situated beside the alafranga lavatory, the bidet became indicative of chic design during the 1950s to the 1970s, even though it meant a waste of space to most people (Figs. 7 and 8 ). ${ }^{48}$ Prominent architects of flats recalled the demand for bidets 
at the time, and considered this to be a 'fashion' and an aspiration toward being modern. Fahri Nişli, who built a mass of multi-storey apartment buildings in Izmir stated:

A bidet was not like the bath. People used the bath. They were more popular than today. The bidet was never adopted, but people asked for it because they thought that it was an indicator of modernity ... it satisfied the need for washing, cleanness, but it took up too much room for the function. We stopped using it in later flats. ${ }^{49}$

According to Muhteşem Giray, an educator and architect of the Ataköy Housing Development Phase I, designers used bidets not only because they were considered fashionable, but also because they suggested better sanitary conditions. ${ }^{50}$ Nejat Ersin, who put bidets in his Modernist flats, stated, 'The bidet was modern. It was asked for because it provided hygiene. ${ }^{51}$ Because of demand, the suppliers provided matching sets of bidets and water closets. Owners of an apartment building in Izmir recalled:

Bidets were sold as a set with the water closets. When our flat was being built in Alsancak during the late 1960s, our father told the contractor that he did not want a bidet in our bathroom because it would take up too much space. But the contractor said that whether he put it in the bathroom or not, we would have to pay for it because it came as a set. ${ }^{52}$

As a consequence of the values attributed to this alien fixture, the bidet carved its space as a stranger within the boundaries of the home. Yet, as a resident of a flat in Ersin's Modernist building in Ankara put it, the bidet was a 'nuisance' to many people. ${ }^{53}$ Its prevalence in the Turkish urban domestic space of a certain income level ended with its general perception as a useless and unhealthy apparatus that took up too much valuable space in the bathroom. Besides, the alafranga water closets included a built-in tap with running water for washing. This feature made the bidet even more irrelevant. Many reported using it for washing their feet. Bidets were usually taken out with renovations to make more room, just as alaturka lavatories were omitted or converted into alafranga ones. In most cases, the space gained from removing the bidet was utilised to accommodate the washing machine, which was becoming standard in domestic interiors during the 1960s.

\section{Conclusion}

The prevalence of Western-style bathroom apparatus in domestic designs is not unique to Turkey; it is a product of global modernity. A shift from traditional fixtures to 'modern' ones indicates a desire to belong to a universal world civilisation. Simultaneously, it signifies an aspiration toward being Western. Whilst representing modernisation, bathroom fixtures operate at a discursive level; they serve as instruments in forming values and beliefs around the concepts of modern, Western, hygienic, comfortable and fashionable. These values and beliefs do not constitute a unified body. Discrepancies, debates and conflicts also contribute to their formation and dissemination. ${ }^{54}$

The conceptualisation of the alaturka lavatory as anachronistic, unhygienic, uncivilised and that which represents past bodily practices that do not suit the present, joins the internalisation of the 
alafranga WC as an embodiment of contemporary lifestyle by people with a certain conceptual formation. Although the acquisition of the water closet cannot be attributed to a specific date, let alone to everybody, its wide acceptance and the consequent internalisation of it as a part of daily life, can be connected to the proliferation of the flat. This growth occurred in the post-World War II era when the multi-storey reinforced concrete dwellings with Modernist aesthetics became ubiquitous worldwide hallmarks of urban landscapes. Flats became popular as a manifestation of modern living as well as an economic and viable solution to the housing problem, in an era of rapid urbanisation in Turkey. Arguably, the massive production of flats served to disseminate the idea of the alafranga water closet as modern.

Flats stabilised the position of the combined family bathroom as a reflection of the Western face of Turkey within domestic space. Mediated through the flat, a combined bathroom with Western fixtures became the norm, while the alaturka lavatory and the traditional hammam became its other. Flat plans, such as the Ataköy, illustrate this dichotomy between the modern and the traditional in the domestic realm. Simultaneously, the inclusion of an alaturka lavatory in addition to a modern family bathroom in these plans suggests negotiations between the new and the old. The materiality of the alaturka and the alafranga elucidates the docility of 'Turkish' bodies. 'Modern' citizens transform their bodily practices in the physicality of the family bathroom. Its other makes their docility more visible. Thus, the bathroom of the modern flat operates as a space that involves the notion of docility.
Michel Foucault explains docility as that 'which joins the analyzable body to the manipulative body. A body is docile that may be subjected, used, transformed, and improved. ${ }^{55}$ In this respect, if we identify the Western-style lavatory as an apparatus that transforms traditional bodily practices and the flat as a modality through which this transformation proliferates, we can also suggest that architectural design is a medium through which a general formula of domination operates. However, it should be stressed that this dominance has no fixed referent; it can change depending on discursive forces. Furthermore, a single authority by no means directly imposes this domination, eg, the state promoting Westernisation. Rather, it emerges from within society itself. In the case of the historical development analysed here, architects, designers, builders, clients and users, all contribute to the discursive formation of the bathroom culture as a facet of modernisation. The physical qualities of the bathroom as the inhabitant's space signify the position of a citizen. This symbolic power arising from the embedded meaning of the bathroom leads to its dissociation from culture and promotes its design as universal space. The materiality of domestic bathrooms, therefore, displays the spatialisation of docility.

At the same time, this study shows that the bathroom becomes a space in which Western concepts and modern technologies merge with shared norms and values. The oral histories reveal this fact, along with the complexity of the interactions with this new equipment and its assumed attributes of hygiene and comfort. In this respect, the use of the bath as a shower basin - or even for storing 
water - and the utilisation of a bidet for washing feet show an interface between tradition and change as well as between the idealised bathroom and daily reality. Whilst propagating Western codes of hygiene and lavatory habits, the bathroom works as a modern space in which not only traditional practices are transformed, but also an environment where new concepts are negotiated. As such, the bathroom embodies the ambiguity of the modern condition. A desire for belonging to the industrial West coexists with a threat of destroying, in Berman's terms, 'everything we know', as a universal idea of modernisation spreads through this ordinary domestic space and its everyday practices.

\section{Notes and references}

1. This concept can be connected to Michel Foucault's exposition around docility and his idea of biopower disciplinary power that manages our lives. According to Foucault, discourses around an object are the prime means by which we are biopowered. See M. Foucault, 'Docile Bodies', in, P. Rabinow, ed., The Foucault Reader (New York, Pantheon, 1984), pp. 179-87. For Foucault's arguments for this idea relating to sexuality, see also M. Foucault, The History of Sexuality (New York, Random House, 1976).

2. Discourse refers to the larger field of statements built form; textual, visual and oral expression; debates and sets of practices - that control the formation of a concept, which includes construct judgements, values and norms: see M. Foucault, The Archaeology of Knowledge (New York, Pantheon Books, 1972).

3. Berman states: 'To be modern is to find ourselves in an environment that promises us adventure, power, joy, growth, transformation of ourselves and the world and, at the same time, that threatens to destroy everything we have, everything we know, everything we are'. See M. Berman, All That is Solid Melts Into Air (Middlesex, Penguin Books, 1982), p. 15.

4. M. İzet, Rehber-i Umur-u Beytiyye, 3 vols (Istanbul, 1903-1911 [Ottoman calendar:1319, 1320, 1326]). According to Uğur Tanyeli, such handbooks aimed to 'format the mind on a new system and to alienate their reader from the traditional'. However, these handbooks did not have any degree of applicability. See U. Tanyeli, 'Westernization and Modernization in the Ottoman Wohnkultur: The Evolution of a New Set of Symbols', in, Y. Sey, ed., Housing and Settlement in Anatolia - A Historical Perspective (Istanbul, The Economic and Social History of Turkey, 1996), p. 295.

5. After the founding of the Turkish Republic, foreign architects, mostly from Germany and Austria, were invited to rebuild the new nation. They included Clemens Holzmeister, Paul Bonatz, Ernst Egli, Bruno Taut, Martin Wagner, Martin Elsaesser, Franz Hillinger, Wilhelm Lihotzky and Margarete Schütte-Lihotzky. However, their contribution was mainly in the public domain. In general, Turkish architects' practice was limited to residential architecture. Turkish architects followed the Modern Movement with enthusiasm during the 1930s.

6. For a study of the bathroom in this context, see A. Cengizkan, Modernin Saati [The Hour of the Modern] (Ankara, Boyut Yayın Grubu, 2002), pp. 143-55.

7. A. Forty, Objects of Desire: Design and Society, 17501980 (London, Thames and Hudson, 1986), pp. 115$18,158-70$.

8. Le Corbusier, Towards a New Architecture (New York, Dover, 1923/1986), p. 122.

9. A. Loos, 'Plumbers' (1898), in, N. Lahiji and D.S. Friedman, eds, Plumbing: Sounding Modern Architecture (New York, Princeton Architectural Press, 1997), p. 19. 


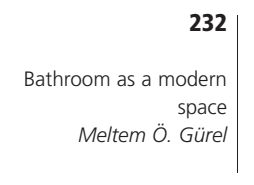

10. Ibid., p. 18. See also B. Campkin and P. Dobraszczyk, 'Architecture and Dirt, Introduction', The Journal of Architecture, vol. 12, no. 4 (2007), p. 347.

11. A. Loos, op. cit., p. 17.

12. S. Giedion, Mechanization Takes Command: A Contribution to Anonymous History (New York and London, W.W. Norton \& Company, 1948/1975), p. 699.

13. Ibid., pp. 699-706.

14. See W. W. Braham, 'Sigfried Giedion and the Fascination of the Tub', in, N. Lahiji and D.S. Friedman, eds, Plumbing, op. cit., p. 219.

15. See also A. Forty, op. cit., p. 240.

16. Alaturka, meaning according to Turkish style, and alafranga, meaning according to European style, are Turkish words that are adapted from French.

17. This was in line with Islamic practices.

18. S. Bozdoğan, Modernism and Nation Building: Turkish Architectural Culture in the Early Republic (Seattle, University of Washington Press, 2001), pp. 56-7.

19. Ibid., pp. 207-209.

20. A. Yücel, 'Typology of Urban Housing in $19^{\text {th }}$ Century Istanbul', in, Y. Sey, ed., Housing and Settlement, op. cit., p. 309.

21. U. Tanyeli, 'Modernism of a Peripheral Metropolis Istanbul: 1930-2005', in, Afife Batur, ed., Architectural Guide to Istanbul: Modern and Contemporary (Istanbul, Ofset Yapımevi, 2006), p. 16.

22. Y. Yavuz and S. Özkan, 'The Final Years of the Ottoman Empire', in, R. Holod and A. Evin, eds, Modern Turkish Architecture (Philadelphia, University of Pennsylvania Press, 1984), pp. 47, 50.

23. Y. Yavuz and S. Özkan, 'Finding a National Idiom: The First National Style', in Modern Turkish Architecture, op. cit., p. 58.

24. Y. K. Karaosmanoğlu, Kiralık Konak [Mansion for Rent] (Istanbul, illetişim Yayınları, 1922/2004), p. 141. Unless otherwise noted, all translations are my own.
25. R. H. Karay, Bugünün Saraylısı [Today's Royalty] (İstanbul, İnkilap ve Aka Kitabevleri, 1954/1985), pp. 341, 342.

26. Arkitekt was an important publication from which architects followed developments in the profession. It started in 1931 under the name of Mimar: its name was changed to Arkitekt in 1933.

27. B. Ünsal, 'Kübik Yapı ve Konfor' [Cubic building and comfort], Arkitekt, vol. 9, no. 3-4 (1939), p. 61.

28. A. Forty, op. cit., pp. 167-68.

29. B. Ünsal, op. cit., p. 61.

30. A. Ziya, 'Binanın İçinde Mimar' [The architect inside the building], Mimar, no. 1 (1931), p. 14.

31. For examples, see H. C. Yalçın, 'Ev ve Apartman' [House and apartment], Yedigün, vol. 9, no. 265 (1938), p. 5; H. C. Yalçın, 'Ev Sevgisi' [Love of home], Yedigün, vol. 5, no. 119 (1935), p. 5; H. C. Yalçın, 'Eski Istanbul' [Old Istanbul], Yedigün, vol. 9, no. 219 (1937), p. 5; P. Safa, 'Bizde ve Avrupada Kübik' [Cubic in Turkey and in Europe], Yedigün, vol. 8 (1936), pp. 6-7. See also S. Bozdoğan, op. cit., pp. 234-39.

32. For an example of the association of flats with financial gains, in the literature, see İ. Tarus, Apartman (istanbul, Varlık, 1950). For an architectural study, see M. Balamir, 'Kira Evinden Kat Evlerine Apartmanlaşma: Bir Zihniyet Dönüşümü Tarihçesinden Kesintiler' [From rental apartments to flat ownership: a historical cross section of a mental transformation], Mimarlık, no. 260 (1994), pp. 29-33.

33. M. Tapan, 'International Style: Liberalism in Architecture', in Modern Turkish Architecture, op. cit., p. 106.

34. Such ideas can be connected to the Weissenhof-Siedlung Exposition (1927) as a showcase of Modernist housing. See K. Kirsch, The Weissenhofsiedlung: Experimental Housing Built for the Deutscher Werkbund, Stuttgart, 1927 (New York, Rizzoli, 1989). 
35. A female user now in her 80 s; interview by the Author, Izmir, 18th October, 2005.

36. A seminal study of the notion of dirt as a relative idea is Purity and Danger by Mary Douglas. The anthropologist emphasises the social nature of the notion of dirt and defines it as 'matter out of place'. For example, 'Shoes are not dirty in themselves, but it is dirty to place them on the dining table; food is not dirty in itself, but it is dirty to leave cooking utensils in the bedroom, or food bespattered on clothing; similarly bathroom equipment in the drawing room...' M. Douglas, Purity and Danger: An Analysis of the Concepts of Pollution and Taboo (London and New York, Routledge, 1966/2002), p. 44.

37. Residents (husband and wife) of a flat in Izmir; interview by the Author, Izmir, 18th October, 2005. It is worth noting that the alaturka lavatory was used by Turkish people of different ethnic and religious groups. Incidentally, the interviewees in this case were Turkish-Jewish residents.

38. For an extensive socio-spatial analysis of flat plans for the middle and upper-middle class, see M. Gürel, 'Domestic Space, Modernity, and Identity: The Apartment in Mid-20th Century Turkey', PhD dissertation, University of Illinois at UrbanaChampaign (2007), chapter 3.

39. Maids' rooms are also seen in earlier plans.

40. E. Menteşe, 'Ataköy Sitesi Hakkında Rapor' [Report on the Ataköy Settlement], Arkitekt, vol. 26, no. 291 (1958), pp. 79-82.

41. A female resident of a Block D unit in Ataköy; interview by the Author, Istanbul, 22nd September, 2006.
42. A female resident of a Block $D$ unit in Ataköy; interview by the Author, Istanbul, 22nd September, 2006.

43. Block $D$ units also had a small wet/laundry room adjacent to the maid's room. This space had a larger floor area and could accommodate a maid's washing activity.

44. Cengiz Bektaş argued that baths were not only alien to Turkish bathing habits, but they also raised the building cost for housing because they took up $1.5 \mathrm{sq}$. m. of extra space per bathroom. See C. Bektaş, Bak Bak Desinler (Istanbul, Evrensel Basım Yayın, 1998), p. 17.

45. N. Ersin, interview by the Author, Ankara, 29th May, 2006.

46. The residents of flats addressed this point during the interviews. This point is also raised in A. Cengizkan, Modernin Saati, op. cit., p. 148.

47. One can argue as to how far-fetched this may be from the current reality in certain cases.

48. The bidet is also seen in earlier house plans.

49. F. Nişli, interview by the Author, Izmir, 18th October, 2005.

50. M. Giray, interview by the Author, Istanbul, September 23rd, 2006.

51. N. Ersin, interview by the Author.

52. Residents (sister and brother) of a block of flats in Izmir; interviews by the Author, Izmir, 5th February, 2006.

53. A resident of a DHMI flat; interview by the Author, Ankara, 29th June, 2006.

54. As Michel Foucault argues, the discursive formation of an object does not rely on consistent views: see M. Foucault, The Archaeology of Knowledge, op. cit. 55. M. Foucault, 'Docile Bodies', op. cit., p. 180. 